\title{
Land Use and Land Cover Dynamics in the North-Eastern Somali Rangelands of Eastern Ethiopia
}

\author{
Fikre Zerfu1 ${ }^{*}$, Abdurehman Mektel$^{2}$, Biniyam Bogale $^{3}$ \\ ${ }^{1}$ Department of Biology, College of Natural and Computational Science, Jigjiga University, Jijiga, Ethiopia \\ ${ }^{2}$ Department of Rural Development and Extention, College of Dryland Agriculture, Jigjiga University, Jijiga, Ethiopia \\ ${ }^{3}$ Department of Sociology, College of Social and Humanity Science, Jigjiga University, Jigjiga, Ethiopia \\ Email: ${ }^{\star}$ fikrezerfu@gmail.com
}

How to cite this paper: Zerfu, F., Mektel, A. and Bogale, B. (2019) Land Use and Land Cover Dynamics in the North-Eastern Somali Rangelands of Eastern Ethiopia. International Journal of Geosciences, 10, 811-832. https://doi.org/10.4236/ijg.2019.109046

Received: May 30, 2019

Accepted: September 24, 2019

Published: September 27, 2019

Copyright $\odot 2019$ by author(s) and Scientific Research Publishing Inc. This work is licensed under the Creative Commons Attribution International License (CC BY 4.0).

http://creativecommons.org/licenses/by/4.0/

\begin{abstract}
Drastic changes have occurred in Siti zone rangeland over nearly the last three decades, due to rapid land conversion dynamics in the area. In the zone, the land-use change over time and space and temporal trends rangeland condition have never been studied. This study analyzed land use and land cover (LULC) change dynamics since the 1980s. Three dates, 1985, 2001 and 2017, Landsat images were used for classification and analysis of the various LULC. The three images were geo-referenced, re-sampled and processed for classification, using the maximum likelihood classifier algorithm. Moreover, field observations and information from local people were used for triangulation to patterns LULC dynamics. From 1985 to 2017, the general trend observed in the land use/cover change in the rangeland resources in the study districts implies a loss of grassland cover was compensated by an increase in cultivated areas, settlement and shrub/bush land cover. Moreover, the encroachments of invasive plant, Prosopis, settlement and the promotion of cultivation to pastoral way of livelihood have exacerbated the decline of rangeland cover. The study findings have shown important changes in the LULC patterns in the north-eastern Somali rangelands of eastern Ethiopia. These trends are certainly the characteristics of a pastoral way of life turn to settlement. This suggests that major changes in the socio-ecological driving forces affecting landscape dynamics have occurred in the last three decades or so.
\end{abstract}

\section{Keywords}

Pastoralist, Remote Sensing, Prosopis, Agriculture, Rangeland, Land Use/Cover 


\section{Introduction}

Somali Regional State (SRS), a major pastoral ecosystem in East Africa, has a total land area of about $327,000 \mathrm{~km}^{2}$, of which about $90 \%$ is classified as rangeland [1]. The rangelands are suitable for pastoralism, more than $80 \%$ of the populations in the SRS depend fully or partially on livestock production for their livelihood [1], so it is the dominant types of land-use systems in the region [2]. Moreover, more than half of Ethiopian pastoralists live in SRS [3]. Pastoralists raise livestock under extensive conditions using natural rangelands as the main forage for their herds. Livestock production serves pastoralists as a source of food, cash, social security and status, transport and pack animals [3]. Besides, pastoralists make a significant contribution to Ethiopian economy [1]. Recent studies on total economic valuation of pastoralism in Ethiopia have shown that $45 \%$ of agricultural GDP is sourced from livestock sector in 2008/09 and almost all of Ethiopia's live animal and meat exports come from pastoral areas of the country [4].

Pastoralism is rarely viewed as a major future form of land use, because well-documented cases of rangeland degradation and the subsequent losses of ecosystem services [5] that threaten the livelihoods of pastoralists, due to its conversion to other land use [6]. For instance, increasing sedentarisation of pastoralists in Ethiopia [7] [8] [9] has heightened pressure on rangeland resources. Demand for firewood, charcoal and construction materials was behind a dramatic 97\% decline in woodland cover between 1972 and 2007 in Afar rangeland of North-eastern Ethiopia [9]. Similarly, declines in the density of multipurpose woody species in Siti and Liben zones of SRS were due to the tree falling for construction material and firewood and charcoal demand of growing nearby towns [3] [8]. Moreover, the conversion of rangelands into cultivated land has been reported in Ethiopia [10] [11]. All these changes have an adverse effect on biodiversity of the ecosystems and sustainability of rangeland productivity [12] [13]. It is, therefore, important to understand the drivers and trends influencing these conversions as a prerequisite for analysis of land use and land cover change processes [14] [15]. Land-use/cover change is a multifaceted process caused by the interaction between anthropogenic and natural factors at different temporal and spatial scales [6] [16]. However, understanding of land-use/cover dynamics and consequences is negligible due to lack of empirical information at local levels, particularly in the Ethiopian rangelands [16] [17]. The Somali rangeland in North-eastern Ethiopia is one notable example where not only no information exists regarding land-use/cover changes, but also the driving factors behind the on-going processes have not been thoroughly investigated. A better understanding of the socio-environment interactions associated with land-use/cover changes requires an in-depth analysis of how the changes affect the physical environment (i.e., land degradation) and the feedback on livelihood strategies and vulnerability of the people [13] [16]. To track landscape structural changes and complexities over time requires the mapping of changes from past to present. In 
this regard, the recently increased availability of satellite data and advancements of remote sensing and geographic information systems (GIS) tools help to quantify and detect land-use/cover changes [16] [18] [19]. In this study, remotely sensed satellite data and people perception data were integrated to investigate land conversion dynamics. Besides, LULC maps can be a powerful tool to compare their changes in an area over time and with them possible to analyze a large area of land in a short period of time [20]. The objective of this study is to analyze the land use and land cover dynamics for the past 32 years (1985-2017) in north-eastern Somali rangelands of eastern Ethiopia. The study provides insight that demonstrates the importance of integrating multiple data sources in analyzing land conversion dynamics. Moreover, the findings are expected to draw recommendations on sustainable rangeland management that might guide decisions and provides insight to policymakers on sustainable pastoral livelihood development programs.

\section{Materials and Methods}

\subsection{The Study Areas}

The Siti administrative zone is located in the north-west of the SRS, lies within $40.554^{\circ}-42.966^{\circ}$ east and $9.265^{\circ}-11.096^{\circ}$ north [3] [21]. The zone is made up of seven districts. Among these, Shinile, Aysha'a and Afdem were selected for this study (Figure 1). Most of the landscapes of the study areas are characterized by low-lying flat terrain (undulating hills), stony outcrops interspersed with plains of loose soil covered by bush and woody grasses, while only insignificant lands are steeply dissected mountains ranging from 950 to $1350 \mathrm{~m}$ above sea level. The zone receives an average of 500 to $700 \mathrm{~mm}$ of rain annually [22] and mean annual temperature ranges between $22.5^{\circ} \mathrm{C}$ and $32.5^{\circ} \mathrm{C}$, depending on the location within the zone [23]. There are two rainy seasons, namely the "Diraa" or "Gu" (short rains) from mid-March to mid-May and the "Karan" (long rains) from mid-July to mid-October. The dry seasons are "Hagaa", from mid-May to mid-July, and "JilaaP", from mid-October to mid-March [2] [22]. The dominant tree species include, Acacia tortilis, few and scattered Acacia senegal, Acacia bussei, Acacia aeforta, Zizyphus mauritania, Acacia mellifera, Balanites rotundifolia and Tamarix aphylla. In most parts of the study Districts, Prosopis juliflora has spread over most parts of the bush land along the main roads and along the seasonal and perennial water courses [2] [3]. The Siti zone has an estimated population of 456,434 , of which 245,928 are males and 210,506 females [24]. It is estimated that $80 \%$ of the 96,988 rural inhabitants in Shinile district, all the 50,043 rural inhabitants in Aysha, and all of the 31,991 rural inhabitants in Afdem are pastoralists. The other $20 \%$ in Shinile are engaged in agro-pastoralism. Less than $5 \%$ of the population is involved in commercial activities in urban or trading centers (Population estimates for 2007 based on 1994 census: in [22]). The main ethnic group in Site is Somali, representing $95 \%$ of the population [24]. 


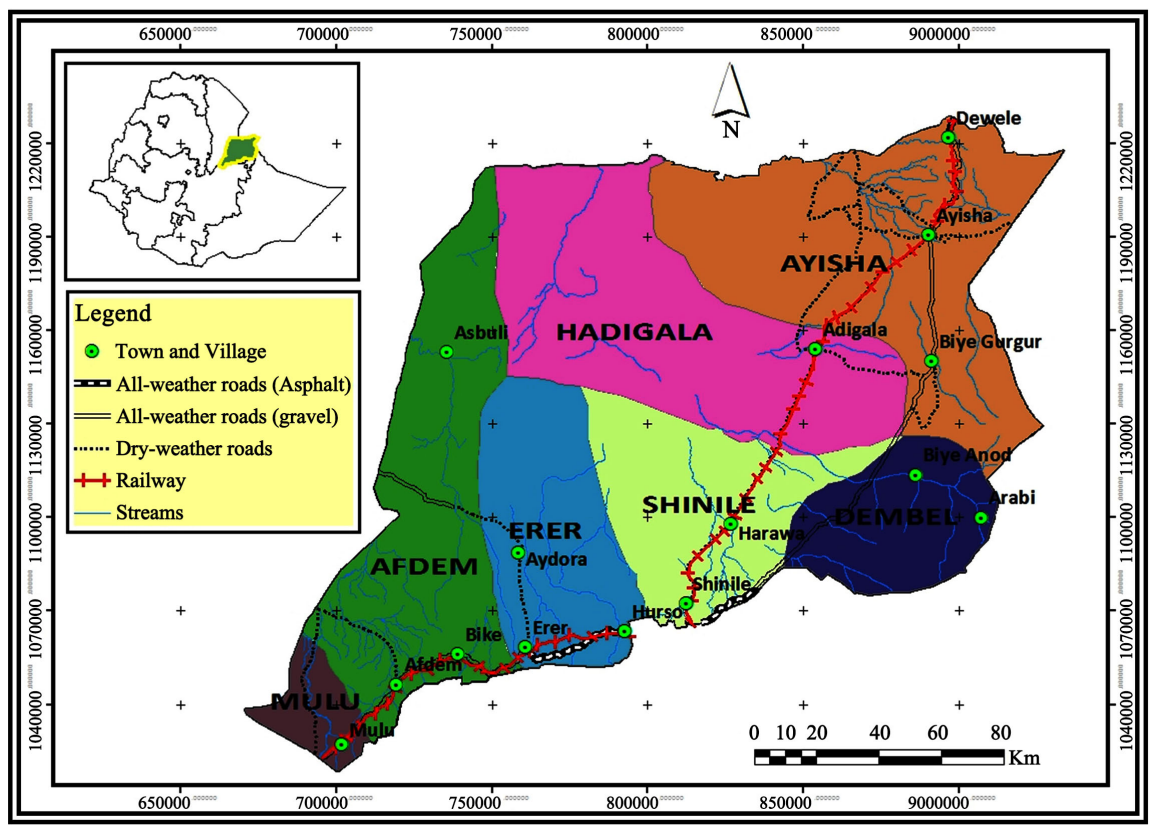

Figure 1. Map of the study areas, Siti zone.

\subsection{Data Collection}

The data used for land use and land cover (LULC) classification in the study were remotely sensed images. Three dates (1985, 2001 and 2017) of Landsat imageries, with path 166 and row 52 and 53 for Ayisha, and path 167 and row 52 and 53 for Afdem and Shinile, were acquired (source: https://earthexplorer.usgs.gov/) and their brief descriptions are summarized in Table 1. These Landsat satellite images were choice in terms of their image quality, with no cloud cover; and the need to ascertain the LULC trends over the 32 year period was considered long enough to generate adequate changes.

The field surveys in study areas were conducted in the July to September of 2018. A hand-held "Garmin 12" Global Position System (GPS) receiver, with \pm 3 meter accuracy, was used to pick some 216 coordinates of selected LULCs as ground control points from the field accompanied by key informants. The locations of these reference data were determined at random by identifying and locating the land use classes of interest in the field and their GPS points and coordinates picked and recorded.

Moreover, participatory tools, such as focus group discussions (FGDs) and key informant interviews (KIIs), and also resource mapping and transect walks, were used to collect qualitative data. A total of four FGD (two female and two male groups) and six KII were conducted in each district (total of twelve FGDs and $18 \mathrm{KII}$ from the three study districts). FGDs using semi-structured interviews were held, and the participants were grouped into two (male and female). The discussion was used as a means of generating ideas regarding issues related to land management and mapping the distribution of resources. Different segment of the community groups, such as elders, women representatives, agriculture or natural resource experts, development agents (DAs), Kebele and district level 
Table 1. Characteristic of Landsat used.

\begin{tabular}{|c|c|c|c|c|}
\hline Satellite Sensor & $\begin{array}{l}\text { No. of } \\
\text { bands }\end{array}$ & $\begin{array}{l}\text { Spectral } \\
\text { resolution }(\mu \mathrm{m})\end{array}$ & $\begin{array}{l}\text { Spatial } \\
\text { resolution }(\mathrm{m})\end{array}$ & $\begin{array}{l}\text { Observation } \\
\text { date }\end{array}$ \\
\hline $\begin{array}{l}\text { Landsat OLI_TIRS } \\
\text { (Operational Land } \\
\text { Imager and Thermal } \\
\text { Infrared Sensor) } \\
\text { (Landsat-8) }\end{array}$ & 11 & $\begin{array}{l}\text { Band 1-7: } 0.43-2.29 \\
\text { Band } 8 \text { (Panchromatic): } \\
0.5-0.68 \\
\text { Band 9: } 1.36-1.38 \\
\text { Band 10-11: } 10.6-12.51\end{array}$ & $\begin{array}{l}\text { Band 1-7 \& 9: } 30 \\
\text { Band 8: } 15 \\
\text { Band 10-11: } 100\end{array}$ & 2017 \\
\hline $\begin{array}{l}\text { Landsat ETM + } \\
\text { (Enhanced Thematic } \\
\text { Mapper Plus) }\end{array}$ & 9 & $\begin{array}{l}\text { Band 1-5: } 0.45-1.75 \\
\text { Band 6: } 10.4-12.5 \\
\text { Band 7: } 2.08-2.35 \\
\text { Band } 8 \text { (Panchromatic): } \\
0.5-0.9\end{array}$ & $\begin{array}{l}\text { Band 1-5 \& 7: } 30 \\
\text { Band 6: } 60 \\
\text { Band 8: } 15\end{array}$ & 2001 \\
\hline $\begin{array}{l}\text { Landsat Multispectral } \\
\text { Sensors (MSS) }\end{array}$ & 4 & $0.5-1.1$ & 60 & 1985 \\
\hline
\end{tabular}

government officials (administrators) and selected pastoralist and agro-pastoralist from the respective study district (Kebele), were key informants who participated in the research. A specific checklist of questions was used to interview the key participants (DAs, Kebele and district government officials and communities' "tribe" leaders). Moreover, FGDs and KIIs were used in the LULC identification, to have a clear understanding of the main categories of LULC as well to find out what types of changes are expected over time, which were used later to triangulate the LULC dynamics in the study areas. Issues intended to be addressed by the research were analyzed using findings from both quantitative and qualitative surveys and applying triangulation method. The basic concept is that integration of quantitative and qualitative data maximizes the strengths and minimizes the weaknesses of each type of data [25] [26] [27].

\subsection{Data Analysis}

In all images, satellite image pre-processing, both geometric rectification and image enhancement were conducted. In this study, the geo-referencing strategy adopted was a GPS ground control points registration [9] [20], using ENVI 4.3 software [28]. The 2017 Landsat- 8 image was geo-referenced using ground control points with a root mean square error (RMSE) of 0.21 pixels. The ETM+ and MSS images were geo-referenced using the 2017 Landsat- 8 image as a master image. The Universal Transverse Mercator (UTM) geographic projection and WGS 1984 Zone 38 North datum were used in geo-referencing the images. To make the Landsat MSS (1985) image compatible, i.e., to be analyzed together with other Landsat images [29], were re-sampled to a $30 \mathrm{~m}$ pixel size using the nearest neighbor re-sampling technique after [30].

Image enhancement was used to increase the details of the images by assigning the image maximum and minimum brightness values to maximum and minimum display values [29]. Landsat data are 8-bit data and the Digital Numbers have values from 0 to 255 . Accordingly, the original low dynamic ranges of the images were stretched to full dynamic range using histogram equalization 
and this made visual interpretation better [20]. The general methodological flow diagram of LULC dynamics were shown in Figure 2.

In this study, for image classification and change detection, both unsupervised and supervised image classification methods were adopted [20] [31]. Unsupervised classification was first carried out to have an idea of representing the overall LULC clusters of pixels. And then supervised classification was employed to categorize the images using ground truths (training areas) which were defined based on the results of unsupervised classification (the cluster of pixels) and ancillary data (Google Earth).

Based on [32], land-use land-cover classification system, five land use land cover classes, bare land, cultivated land, grassland, settlements/built-up areas and shrub land, were classified in accordance with [33] [34] classification criteria for East African rangelands (Table 2). For this identification, some of the LULC classes was required frequent field visits and FGDs with pastoralist and also consulted secondary data, to have a clear understanding of the main categories of LULC as well to find out what types of changes are expected over time. The classification algorithm used in the ENVI 4.3 software [28] was supervised maximum likelihood classifier (MLC). Image differencing was performed in ArcGIS 10.1 software [35] to ascertain the levels of change from one land use type to the other and by how much in terms of area in hectare.

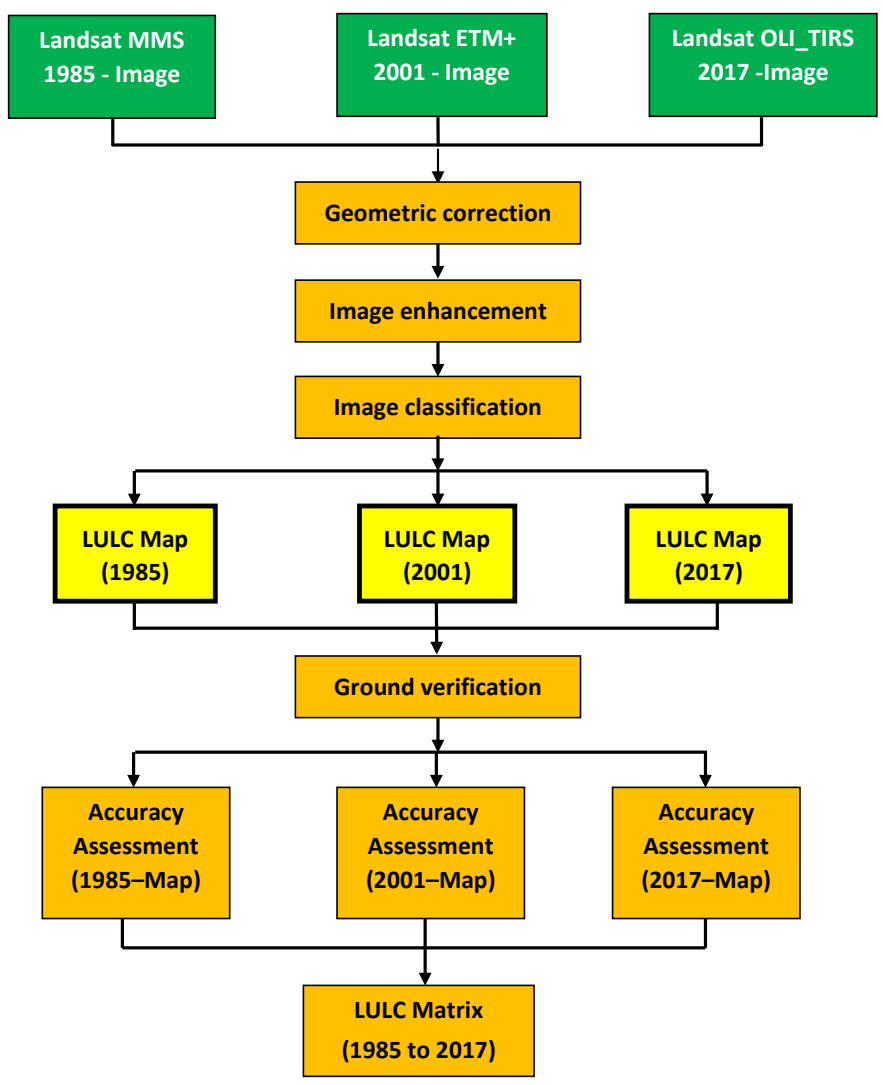

Figure 2. Flow chart of the process followed to create the data on the land cover classification analysis. 
Table 2. Description of land use and land cover types identified.

\begin{tabular}{|c|c|}
\hline LULC Classes & LULC Description \\
\hline Shrub land & $\begin{array}{l}\text { Land covered by small trees, bushes, and shrubs, and in some cases such lands are } \\
\text { mixed with grasses; It is less dense than the woodland. }\end{array}$ \\
\hline Grassland & $\begin{array}{l}\text { Small grasses and herbs are the predominant natural vegetation. It also includes } \\
\text { land with scattered or patches of trees and this land cover is used for grazing and } \\
\text { browsing. }\end{array}$ \\
\hline Cultivated land & Areas allotted to extended crop production, Cropping fields. \\
\hline Settlement & $\begin{array}{l}\text { This is a land use dominated by a permanent settlement area that included towns } \\
\text { and rural villages and roads. }\end{array}$ \\
\hline Bare land & $\begin{array}{l}\text { A non-vegetative land, which mainly covered by rock outcrops, sand, and lava } \\
\text { (volcanic ash). }\end{array}$ \\
\hline
\end{tabular}

Classifying LULC maps from satellite images; require a quality check on the acceptability of the results of the classes that have been trained and assigned to each pixel in the image, i.e., an accuracy assessment were conducted. The use of aerial photographs and previous LULC classes as well as the use of GPS shows identified ground control points (GCPs), which are, in most instances land use types. The area of interest has invariably been used to corroborate the accuracy of LULC classification [36]. The classified LULC maps may contain some sort of errors because of several factors, from classification technique to the methods of satellite data capture. In order to use the classified maps, the errors must be quantitatively evaluated through classification accuracy assessment and intended to produce information that describes reality. Therefore, an accuracy classification assessment was performed through the standard method [37]. The accuracy of the 1985 image was determined form expert knowledge of the study Districts along discussion with elders. The 2001 accuracy were determined using co-ordinate points of land uses obtained from the Google Earth image. The 2017 classification was assessed using the GPS points of selected LULC types collected in the field. These were used in the accuracy assessment procedure. In the absence of base maps and aerial photographs of the study area, GPS points of 216 LULC types were selected as GCPs to ascertain the accuracy of the classification. This was done using the Kappa hat statistical analysis. Thus, total accuracy, and Kappa statistics were computed. In principle, all the output maps have to meet the minimum $85 \%$ accuracy [32].

Visual comparison of features and matrix analysis (image differencing) were adopted to determine the LULC change detection [38]. Areas that are converted from each class to any of the other classes were computed and the change directions were also determined. The land-use/cover changes between the three periods (i.e., 1985, 2001 and 2017) were quantified and a change detection matrix of "from-to" change was derived [39] [40] to show land cover class conversion transitions during the 30-year period by overlaying the 1985 and 2017 images. In relation to the transition matrix, net change and net change-to-persistence ratio [9] [39] [40] were computed to show the resistance and vulnerability of a given 
land-use/cover type. All, this was executed in ArcGIS cross-tabulation tool functionality of ArcMap 10.1 software [35].

\section{Result}

\subsection{Land Use Land Cover Dynamics in Afdem District}

The accuracy assessment was conducted for all the classified imageries (maps) via a standard method. The producer's, user's and total accuracy and the Kappa statistics were computed. The overall classification accuracy of the images yielded a Kappa hat statistic of $87.94 \%, 85.2 \%$ and $89.72 \%$ for the 1985, 2001 and the 2017 images, respectively. This is an indication of classification accuracy of moderately substantial to almost perfect agreement (Table 3).

The LULC maps that show spatial distribution of five LULC classes for 1985, 2001 and 2017 were given in Figure 3 the area coverage of the LULC categories were summarized in Table 4. In all study years more than half of the district coverage was bare land that includes exposed rock surface, exposed sand soil and volcanic lava (Table 4 and Figure 3). The study revealed the grassland was intact in the first study period while overtime-decreased trends of conversion of grassland to shrub land were observed. As a result, the share of shrub land increased from $7.2 \%$ (41,370 ha) in 1985 to $19 \%$ (108,680 ha) in 2001, to $16.9 \%$ $(96,290 \mathrm{ha})$ in 2017. Expansion in the extent of cultivated land and settlement also followed the same trend as shrub land did, and their area coverage in 2017 was about 4.2 times higher than its original cover of 1985 .

Table 3. LULC classes and accuracy assessment of the classified images of Afdem district.

\begin{tabular}{ccccccc}
\hline & \multicolumn{7}{c}{ Accuracy (\%) } \\
\cline { 2 - 7 } LULC Classes & \multicolumn{2}{c}{1985} & \multicolumn{2}{c}{2001} & \multicolumn{2}{c}{2017} \\
\cline { 2 - 7 } & Producer's & User's & Producer's & User's & Producer's & User's \\
\hline Shrub land & 76.67 & 80.6 & 83.3 & 57.14 & 80.6 & 70.59 \\
Grassland & 76.47 & 100 & 86.6 & 89.8 & 86.3 & 88.6 \\
Cultivated land & 87.24 & 85.24 & 85.8 & 88.8 & 86.8 & 76.67 \\
Settlement & 82.31 & 82.31 & 88.64 & 97.5 & 95.5 & 96.8 \\
Bare land & 66.67 & 57.14 & 79.8 & 85 & 87.4 & 89.5 \\
Over all accuracy & & $\mathbf{8 7 . 9 4}$ & & $\mathbf{8 5 . 2}$ & & $\mathbf{8 9 . 7 2}$ \\
\hline
\end{tabular}

Table 4. Areas of LULC of Afdem district between 1985 and 2017.

\begin{tabular}{ccccccc}
\hline Years & \multicolumn{2}{c}{1985} & \multicolumn{2}{c}{2001} & \multicolumn{2}{c}{2017} \\
\hline LULC class & Area (ha) & $\%$ & Area (ha) & $\%$ & Area (ha) & $\%$ \\
\hline Shrub land & 41,375 & 7.2 & 108,679 & 19 & 96,287 & 16.9 \\
Grassland & 182,986 & 32 & 128,828 & 22.5 & 106,508 & 18.6 \\
Cultivated land & 13,126 & 2.3 & 30,947 & 5.4 & 25,943 & 4.5 \\
Settlement & 5188 & 0.91 & 29,533 & 5.2 & 50,405 & 8.8 \\
Bare land & 328,849 & 57.5 & 273,537 & 47.9 & 292,381 & 51.2 \\
Total & 571,524 & 100 & 571,524 & 100 & 571,524 & 100 \\
\hline
\end{tabular}



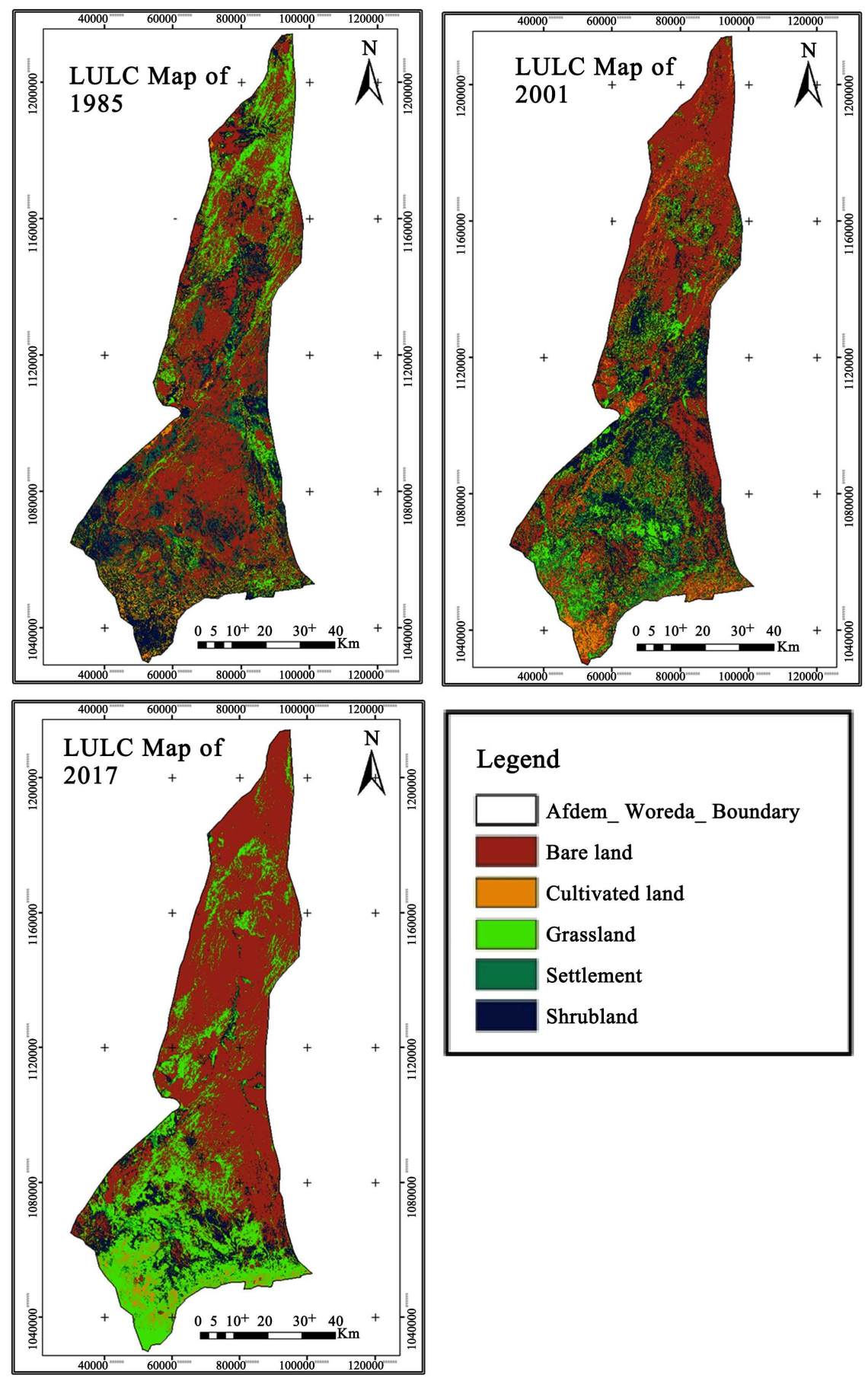

\section{Legend}

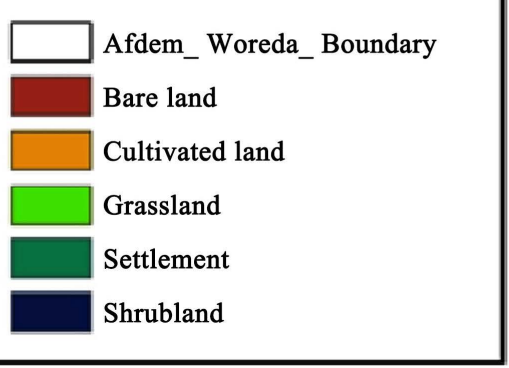

Figure 3. Afdem District LULC Map of Years 1985, 2001 and 2017.

The LULC class trend analysis shows the direction in which the various classes are heading using their respective initial years of comparison as the base. Between 1985 and 2001, the 16-year period, grassland decreased by 54,158 ha, and also bare land decreased by 55,312 ha. While shrub land, settlement and cultivated land areas increasing by 67,304 ha, 17,824 ha and 24,345 ha respectively (Table 4). This was the case since the district has and continues to its vegetation cover in the area began to decline tremendously, and most of the land, particu- 
larly, the grassland cover had been converted into shrub land, cultivated land and settlement.

The LULC trends between 2001 and 2017 indicated that human activities had begun taking considerable toll on the land use and cover types. Settlement and bare land increased by 20,870 ha and 18,880 ha, respectively (Table 4). Grassland, shrub land and cultivated land decreased by 22,310 ha, 12,390 ha and 5050 ha, respectively (Table 4). The significant decrease in the grassland was due to rapid urbanized settlements that were converted these grassland and shrub land areas over the period. As a result, the settlement was showed a significant incensement in area of coverage. Today, most of the grassland areas have been converted to settlement and bare land.

The land use change matrices depict the changes in extent and directions in LULC classes. As evident from Table 5, between 1985 and 2001, the area of LULC persistence or retention, constituted a total of 256,787 ha representing about $45 \%$ of the total area. "Persistence" is indicated in Table 5 as the bolded diagonal elements for each land-use/cover class. The most LULC conversion occurring within this period is the conversion of bare land into grassland a total conversion area of 69,253 ha. As seen in Table 5, there was a substantial increase in settlement uses by 67,304 ha representing $62 \%$ change over the period. This was gained from the conversion of bare land as well as grassland by 67,948 ha and 25,224 ha, respectively.

The LULC matrix from 2001 to 2017, portrayed major land use conversions/transitions from one land use class to another. At this time, various land use class types were in real transition of change after the base year's land use cover anomalies. This was particularly so for the diagonal matrix of land uses that maintained their types in the following reference years by a decrease over the previous reference year at a total of $151,532 \mathrm{ha}$. This was about $26 \%$ of the total land area. The highest conversions from one type to another, however, was from grassland and shrub land to bare land cover with 79,659 ha and 62,851 ha respectively in 2017 (Table 6).

Table 5. LULC change matrices of the afdem district (1985-2001).

\begin{tabular}{cccccccc}
\hline & \multirow{7}{*}{ LULC Class } & \multicolumn{7}{c}{ 2001 Image } & \multirow{2}{*}{ 1985 Total } \\
\cline { 2 - 6 } & & $\mathrm{BL}$ & $\mathrm{CL}$ & $\mathrm{GL}$ & $\mathrm{SET}$ & $\mathrm{SL}$ & \\
\hline \multirow{2}{*}{1985} & $\mathrm{BL}$ & $\mathbf{1 9 0 , 2 4 6}$ & 4808 & 61,419 & 4428 & 67,948 & 328,849 \\
Images & $\mathrm{CL}$ & 4893 & $\mathbf{3 7 7 6}$ & 1893 & 2446 & 118 & 13,126 \\
& $\mathrm{GL}$ & 69,253 & 21,922 & $\mathbf{4 7 , 5 4 5}$ & 19,042 & 25,224 & 182,986 \\
& $\mathrm{SET}$ & 987 & 186 & 2190 & $\mathbf{8 2 7}$ & 998 & 5188 \\
& SL & 8158 & 255 & 15,781 & 2790 & $\mathbf{1 4 , 3 9 1}$ & 41,375 \\
& 2001 Total & 273,537 & 30,947 & 128,828 & 29,533 & 108,679 & 571,524 \\
& Change (ha) & $-55,312$ & 17,824 & $-54,158$ & 24,345 & 67,304 & \\
& Change (\%) & -20 & +58 & -42 & +82 & +62 & \\
\hline
\end{tabular}

$\mathrm{BL}=$ Bare land $; \mathrm{GL}=$ Grasslands SET $=$ Settlement CL = Cultivated land; SL = Shrub Land. Bolded diagonal elements represent proportions of each LULC class that were static (persisted) between 1985 \& 2001 
Table 6. LULC change matrices of the afdem district (2001-2017).

\begin{tabular}{cccccccc}
\hline & \multirow{6}{*}{ LULC Class } & \multicolumn{5}{c}{ 2017 Image } & \multirow{2}{*}{ 2001 Total } \\
\cline { 3 - 7 } & & BL & CL & GL & SET & SL & \\
\hline \multirow{2}{*}{2001} & BL & 130,026 & 7342 & 76,281 & 11,011 & 48,877 & 273,537 \\
Images & CL & 5052 & 2005 & 14,327 & 99 & 9464 & 30,947 \\
& GL & 79,659 & 6664 & 5661 & 14,978 & 21,866 & 128,828 \\
& SET & 15,315 & 6491 & 675 & 3306 & 3746 & 29,533 \\
& SL & 62,329 & 3441 & 9564 & 21,011 & 12,334 & 108,679 \\
& 2017 Total & 292,381 & 25,943 & 106,508 & 50,405 & 96,287 & 571,524 \\
& Change (ha) & 18,880 & -5050 & $-22,310$ & 20,870 & $-12,390$ & \\
& Change (\%) & +7 & -20 & -21 & +41 & -13 & \\
\hline
\end{tabular}

$\mathrm{BL}=$ Bare land $; \mathrm{GL}=$ Grasslands; $\mathrm{SET}=$ Settlement $\mathrm{CL}=$ Cultivated land; $\mathrm{SL}=$ Shrub Land . Bolded di agonal elements represent proportions of each LULC class that were static (persisted) between 1985 \& 2001.

Furthermore, there was a substantial increase in settlement uses by 20,870 ha representing $41 \%$ change over the period. This was gained from the conversion of grasslands as well as shrub land by 14,978 ha and 21,011 ha, respectively (Table 6).

\subsection{Land Use Land Cover Dynamics in Shinile District}

Like the previous Afdem district, the accuracy assessment of all the classified imageries from Shinile district was conducted in a standard way. For all maps, the producer's, user's and total accuracy and the Kappa statistics were computed. Overall, the maps met the required minimum $85 \%$ accuracy (Table 7 ).

For the whole study period, much of the district coverage was the natural vegetation, including, shrub land and grassland (Table 8 and Figure 4); while the classes of grassland (44.7\%) in 1985, shrub land (35\%) in 2001, and bare land (43.8\%) in 2017 comprised the largest share of the total area. The study also revealed increased trends of conversion of grassland to shrub land. As a result, the share of shrub land increased from $16.7 \%(62,440 \mathrm{ha})$ in 1985 to $28.7 \%(107,230$ ha) in 2017. Similarly, cultivated land showed increased in trends. Like the previous district, the grassland cover was diminishing continuously from its level of $44.7 \%$ (167,261 ha) in 1985 to $17.1 \%$ (64,085 ha) in 2017. However, areas of bare land and settlement showed inconsistent pattern of conversions.

The land use change matrices depicted the changes in the extent and directions in LULC classes. Between 1985 and 2001, the area of LULC persistence or retention, constituted a total of 107,281 ha representing about $29 \%$ of the total area (Table 9). As evident from Table 9, there have been a remarkable increases in the area of shrub land (68,296 ha), cultivated land (9121 ha), settlement (5223 ha), and bare land (7055 ha) during the first study period although some portion of their extents were converted to other LULC classes. In contrast, the only shrinkage was evident in the extent of grassland (89,691 ha) however the added area from the classes of bare land (20,186 ha), settlement (853 ha), shrub land 
(9956 ha) and cultivated land (166 ha) could not compensated its losses in the course of the first period.

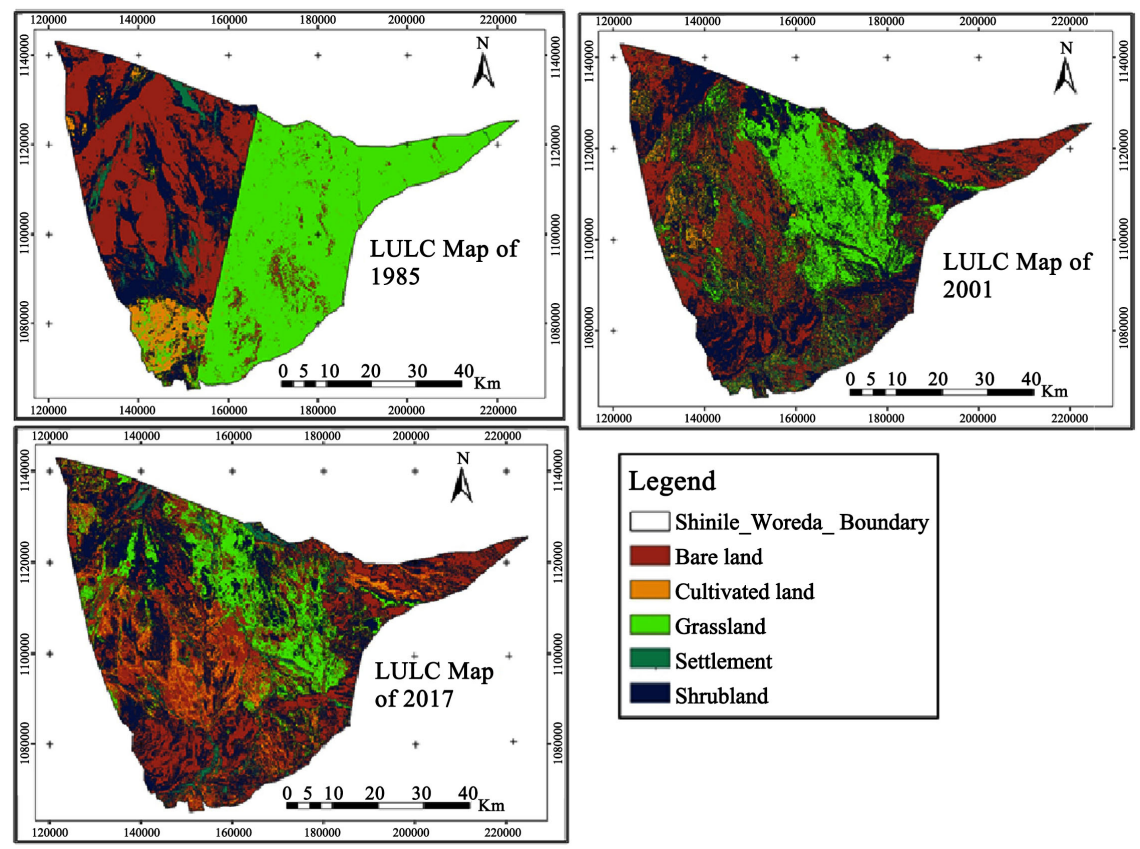

Figure 4. Shinile District LULC Map for Years 1985, 2001 and 2017.

Table 7. LULC classes \& accuracy assessment of the classified images of Shinile district.

\begin{tabular}{ccccccc}
\hline & \multicolumn{7}{c}{ Accuracy (\%) } \\
\cline { 2 - 7 } LULC Classes & \multicolumn{2}{c}{1985} & \multicolumn{2}{c}{2001} & \multicolumn{2}{c}{2017} \\
\cline { 2 - 7 } & Producer's & User's & Producer's & User's & Producer's & User's \\
\hline Shrub land & 87.08 & 94.87 & 76.79 & 76.74 & 81.64 & 81.4 \\
Grassland & 81.54 & 87.18 & 88.42 & 86.36 & 87.20 & 80.85 \\
Cultivated land & 90.60 & 82.98 & 94.87 & 92.63 & 93.21 & 93.02 \\
Settlement & 84.08 & 80 & 96.79 & 96.74 & 95.5 & 100 \\
Bare land & 93.91 & 100 & 87.18 & 88.42 & 86.56 & 86.05 \\
Over all accuracy & \multicolumn{2}{c}{$\mathbf{8 7 . 1 5}$} & & $\mathbf{8 8 . 9 1}$ & $\mathbf{8 8 . 9 6}$ & \\
\hline
\end{tabular}

Table 8. Areas of LULC of Shinile district between 1985 and 2017.

\begin{tabular}{ccccccc}
\hline Years & \multicolumn{2}{c}{1985} & \multicolumn{2}{c}{2001} & \multicolumn{2}{c}{2017} \\
\hline LULC class & Area (ha) & $\%$ & Area (ha) & $\%$ & Area (ha) & $\%$ \\
\hline Shrub land & 62,440 & 16.7 & 130,732 & 35 & 107,230 & 28.7 \\
Grassland & 167,261 & 44.7 & 77,570 & 20.7 & 64,085 & 17.1 \\
Cultivated land & 16,457 & 4.4 & 25,578 & 6.8 & 27,658 & 7.4 \\
Settlement & 9962 & 2.7 & 15,185 & 4.1 & 11,151 & 3 \\
Bare land & 117,882 & 31.5 & 124,937 & 33.4 & 163,878 & 43.8 \\
Total & 374,002 & 100 & 374,002 & 100 & 374,002 & 100 \\
\hline
\end{tabular}


Table 9. LULC change matrices of the shinile district (1985-2001).

\begin{tabular}{cccccccc}
\hline & \multirow{6}{*}{ LULC Class } & \multicolumn{5}{c}{ 2001 Image } & \multirow{2}{*}{ 1985 Total } \\
\cline { 2 - 6 } & BL & CL & GL & SET & SL & \\
\hline \multirow{2}{*}{1985} & BL & $\mathbf{3 8 , 2 6 7}$ & 11,899 & 20,186 & 4795 & 42,735 & 117,882 \\
Images & CL & 5301 & $\mathbf{8 8}$ & 166 & 136 & 10,766 & 16,457 \\
& GL & 57,577 & 5952 & 46,409 & 6675 & 50,648 & 167,261 \\
& SET & 3219 & 718 & 853 & $\mathbf{5 5 3}$ & 4619 & 9962 \\
& SL & 20,573 & 6921 & 9956 & 3026 & 21,964 & 62,440 \\
& 2001 Total & 124,937 & 25,578 & 77,570 & 15,185 & 130,732 & 374,002 \\
& Change (ha) & 7055 & 9121 & $-89,691$ & 5223 & 68,292 & \\
& Change (\%) & +6 & +36 & -115 & +34 & +52 & \\
\hline
\end{tabular}

$\mathrm{BL}=$ Bare land; $\mathrm{GL}=$ Grasslands; $\mathrm{SET}=$ Settlement $\mathrm{CL}=$ Cultivated land; $\mathrm{SL}=$ Shrub Land. Bolded diagonal elements represent proportions of each LULC class that were static (persisted) between 1985 \& 2001.

In the second study period (2001-2017), the areas of bare land and cultivated land have been increased by 38,941 ha and 2080 ha respectively despite their initial areas in 2001 simultaneously were lost to grassland, shrub land and settlement (Table 10). As seen in Table 10, the most important contributors to the increase of bare land and cultivated land were shrub land and grassland. Moreover, at this time, the land uses that maintained their types in the following reference years by an increase over the previous reference year at a total of 131,644 ha. This was about $35 \%$ of the total land area.

Thus, from all classes in the Shinile district, shrub land (66,778 ha) in the second period also noticeably continued to be the major area loser to bare land while grassland (19,296 ha) to bare land. In contrast, settlement, shrub land and grassland classes were lost their original extents and transformed to other classes.

\subsection{Land Use Land Cover Dynamics in Ayisha District}

Likewise the other two districts, for Ayisha, the accuracy assessment of all the classified imageries were conducted in a standard way. For all images, the produce's, user's and total accuracy and the Kappa statistics were computed. In general, all images met the required minimum $85 \%$ accuracy (Table 11 ).

For the whole study period, much of this district also covered with natural vegetation, including shrub land and grassland (Table 12 and Figure 5); while the classes of bare land (exposed rock surface and exposed sand soil surface) comprised the largest share of the total area in all times. The study also revealed increased trends of conversion of much of grassland area to settlement. As a result, the coverage of settlement surprisingly increased from $6.5 \%$ (47,843 ha) in 1985 to $10.4 \%$ (76,123 ha) in 2017. Like the previous two Districts, the grassland cover was diminishing continuously from its level of $14.5 \%$ (105,955 ha) in 1985 to $9.3 \%(67,862 \mathrm{ha})$ in 2010 . However, areas of shrub land and bare land showed expected inconsistent pattern of conversions. 

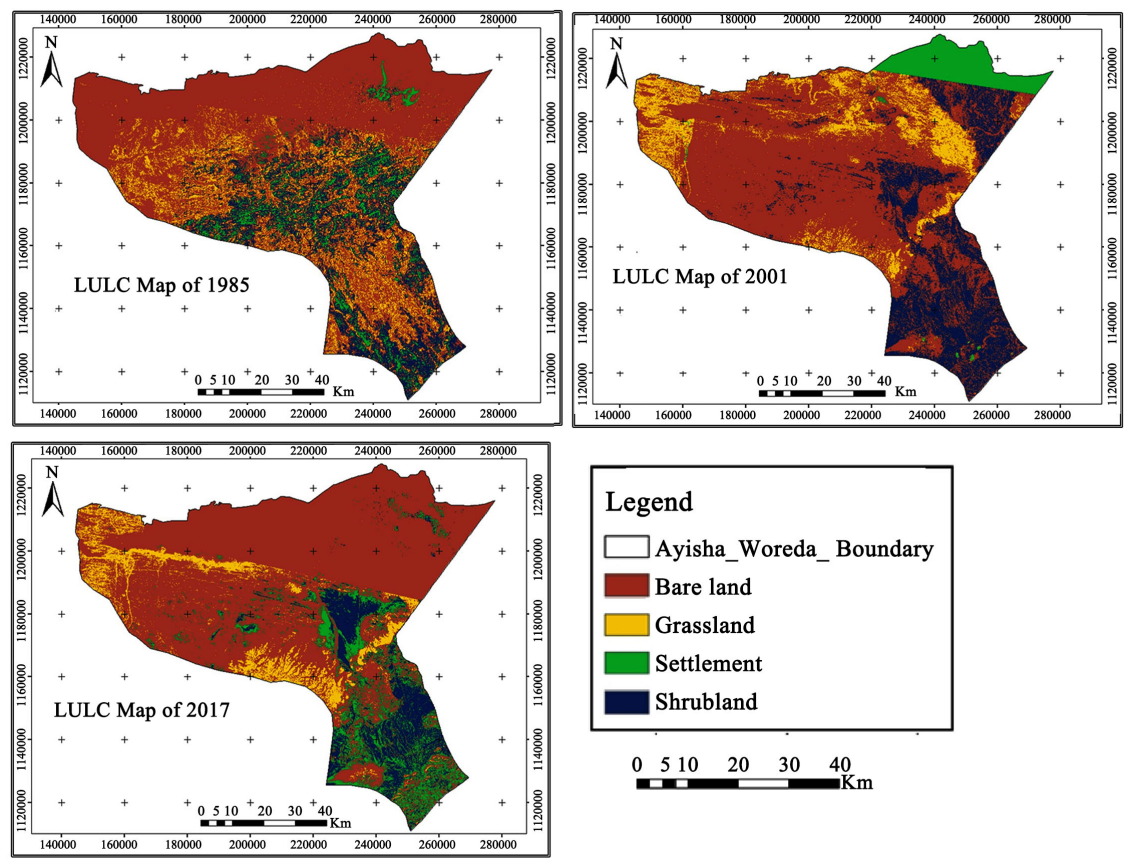

Figure 5. Ayisha District LULC Map for Years 1985, 2001 and 2017.

Table 10. LULC change matrices of the shinile district (2001-2017).

\begin{tabular}{cccccccc}
\hline & \multirow{6}{*}{ LULC Class } & \multicolumn{5}{c}{ 2017 Image } & \multirow{2}{*}{ 2001 Total } \\
\cline { 2 - 6 } & & BL & CL & GL & SET & SL & \\
\hline \multirow{2}{*}{2001} & BL & 130,026 & 7342 & 76,281 & 11,011 & 48,877 & 273,537 \\
Images & CL & 5052 & 2005 & 14,327 & 99 & 9464 & 30,947 \\
& GL & 79,659 & 6664 & 5661 & 14,978 & 21,866 & 128,828 \\
& SET & 15,315 & 6491 & 675 & 3306 & 3746 & 29,533 \\
& SL & 62,329 & 3441 & 9564 & 21,011 & 12,334 & 108,679 \\
& 2017 Total & 292,381 & 25,943 & 106,508 & 50,405 & 96,287 & 571,524 \\
& Change (ha) & 18,880 & -5050 & $-22,310$ & 20,870 & $-12,390$ & \\
& Change (\%) & +7 & -20 & -21 & +41 & -13 & \\
\hline
\end{tabular}

$\mathrm{BL}=$ Bare land $; \mathrm{GL}=$ Grasslands; SET $=$ Settlement $\mathrm{CL}=$ Cultivated land; $\mathrm{SL}=$ Shrub Land. Bolded di agonal elements represent proportions of each LULC class that were static (persisted) between 1985 \& 2001.

Table 11. LULC classes \& accuracy assessment of the classified images of Ayisha district.

\begin{tabular}{cccccccc}
\hline & \multicolumn{7}{c}{ Accuracy (\%) } \\
\cline { 2 - 7 } LULC Classes & \multicolumn{2}{c}{1985} & \multicolumn{2}{c}{2001} & \multicolumn{2}{c}{2017} \\
& \cline { 2 - 7 } & Producer's & User's & Producer's & User's & Producer's & User's \\
\hline Shrub land & 84.06 & 76.6 & 76.79 & 76.74 & 81.64 & 81.4 \\
Grassland & 80.38 & 79.07 & 88.42 & 86.36 & 87.20 & 80.85 \\
Settlement & 91.97 & 75.47 & 96.79 & 96.74 & 95.5 & 100 \\
Bare land & 86.37 & 92.31 & 87.18 & 88.42 & 86.56 & 86.05 \\
Over all accuracy & \multicolumn{2}{c}{$\mathbf{8 7 . 2 4}$} & \multicolumn{2}{c}{$\mathbf{8 6 . 9 1}$} & $\mathbf{8 8 . 9 6}$ \\
\hline
\end{tabular}


Table 12. Areas of LULC of Ayisha district between 1985 and 2017.

\begin{tabular}{ccccccc}
\hline Years & \multicolumn{2}{c}{1985} & \multicolumn{2}{c}{2001} & \multicolumn{2}{c}{2017} \\
\hline LULC class & Area (ha) & $\%$ & Area (ha) & $\%$ & Area (ha) & $\%$ \\
\hline Shrub land & 97,409 & 13.3 & 128,495 & 17.6 & 66,818 & 9.1 \\
Grassland & 105,955 & 14.5 & 98,046 & 13.4 & 67,862 & 9.3 \\
Settlement & 47,843 & 6.5 & 47,793 & 6.5 & 76,123 & 10.4 \\
Bare land & 480,458 & 65.7 & 457,331 & 62.5 & 520,862 & 71.2 \\
Total & 731,665 & 100 & 731,665 & 100 & 731,665 & 100 \\
\hline
\end{tabular}

The change matrices depicted the changes in extent and directions in LULC classes. Between 1985 and 2001, the area of LULC persistence or retention, constituted a total of 328,381 ha representing about $45 \%$ of the total area (Table 13). As evident from Table 13 there has been a remarkable increase in the area of shrub land (31,086 ha), during the first study period despite some portion of their initial extents were converted to other LULC classes. Whereas, a simultaneous shrinkage was observed in the area of bare land $(23,127 \mathrm{ha})$ and grassland (7909 ha), even though considerable area of land added to it from shrub land $(61,220.5 \mathrm{ha})$ and grassland $(75,103 \mathrm{ha})$.

In 2001-2017, the areas of bare land and settlement have been increased by 63,531 ha, 28,330 ha respectively, despite their initial areas of 2001 were simultaneously lost to grassland and shrub land (Table 14). Moreover, at this time, the land uses that maintained their types in the following reference years by an increase over the previous reference year at a total of 446,440 ha. This was about $61 \%$ of the total land area. As shown in Table 14, the most important contributor to the increase of bare land was grassland while shrub land lost to settlement. Accordingly, grassland (30,184 ha), just like other districts, noticeably continued to be the major area contributor to bare land.

\section{Discussion}

In both study areas, Afdem and Shinile districts, five major LULC types (bare land, cultivated land, grassland, settlement and shrub land) were identified. However, in Afdem district, there was no cultivated land, and LULC types were four. There were high values of overall classification accuracy (85.2\% - 89.72\%) were attained; these indicated a strong agreement between the classified LULC patterns and the geographical data (ground truths). The Kappa statistic is generally accepted as a measure of classification accuracy for both the model as well as the user of the model of classification [41]. Kappa values are characterized $<0$ as indicative of no agreements and $0-0.2$ as slight, $0.2-0.41$ as fair, $0.41-0.60$ as moderate, $0.60-0.80$ as substantial and $0.81-1.0$ as almost perfect agreement [20] [41] [42]. Then it is possible to use the output maps that meet the requirements for the intended application. Moreover, the overall accuracies were very 
Table 13. LULC change matrices of the ayisha district (1985-2001).

\begin{tabular}{|c|c|c|c|c|c|c|}
\hline & \multirow{2}{*}{ LULC Class } & \multicolumn{4}{|c|}{2001 Image } & \multirow{2}{*}{1985 Total } \\
\hline & & $\mathrm{BL}$ & GL & SET & SL & \\
\hline & $\mathrm{BL}$ & 289,245 & $80,633.5$ & 46,755 & 63,825 & 480,458 \\
\hline 1985 & GL & 75,103 & 8615 & 108 & 22,129 & 105,955 \\
\hline \multirow[t]{5}{*}{ Images } & SET & 31,763 & 2914.5 & 567.5 & 12,598 & 47,843 \\
\hline & SL & $61,220.5$ & 5883 & 362.5 & 29,943 & 97,409 \\
\hline & 2001 Total & 457,331 & 98,046 & 47,793 & 128,495 & 731,665 \\
\hline & Change (ha) & $-23,127$ & -7909 & -50 & $+31,086$ & \\
\hline & Change (\%) & -5 & -8 & -0.1 & +24 & \\
\hline
\end{tabular}

$\mathrm{BL}=$ Bare land $; \mathrm{GL}=$ Grasslands; SET $=$ Settlement; $\mathrm{SL}=$ Shrub Land. Bolded diagonal elements represent proportions of each LULC class that were static (persisted) between 1985 \& 2001.

Table 14. LULC change matrices of the ayisha district (2001-2017).

\begin{tabular}{|c|c|c|c|c|c|c|}
\hline & \multirow{2}{*}{ LULC Class } & \multicolumn{4}{|c|}{2017 Image } & \multirow{2}{*}{2001 Total } \\
\hline & & $\mathrm{BL}$ & GL & SET & SL & \\
\hline & $\mathrm{BL}$ & 371,456 & 30,555 & 26,153 & 29,167 & 457,331 \\
\hline 2001 & GL & 61,247 & 36,670 & 80 & 49 & 98,046 \\
\hline \multirow[t]{5}{*}{ Images } & SET & 45,959 & 338 & 1104 & 392 & 47,793 \\
\hline & SL & 42,200 & 299 & 48,786 & 37,210 & 128,495 \\
\hline & 2017 Total & 520,862 & 67,862 & 76,123 & 66,818 & 731,665 \\
\hline & Change (ha) & $+63,531$ & $-30,184$ & $+28,330$ & -61677 & \\
\hline & Change (\%) & +12 & -45 & +37 & -92 & \\
\hline
\end{tabular}

$\mathrm{BL}=$ Bare land; GL = Grasslands; SET = Settlement; SL = Shrub Land. Bolded diagonal elements represent proportions of each LULC class that were static (persisted) between 1985 \& 2001.

good with the user and producer accuracies also being considerably high for almost all the land use classes. This is an indication of acceptable LULC classification accuracy for images for which there were no available ground truth data as well as aerial photographs nor a pre-existing land use land cover maps.

In all study districts, there were experienced substantial and increasing rates of land-use/cover changes during 32 years from 1985 to 2017. There have been persistent changes, both spatially and temporally, resulting in an average $41 \%$ of the total area experiencing transitional changes among the land cover types. The poor vegetation cover observed in 2001 compared to 1985 and 2017 indicates that most of the vegetation types suffered from short-term direct and indirect drought effects. Supporting the above idea, the FGD held in Afdem confirmed that between 2007 and 2010 the expansion of bear land and lose of indigenous grassland species as well as trees fall down were observed. Moreover, rain fall and temperature variability research findings showed that in the last 30 years, in Shinile, Ayisha and Afdem stations, the annual maximum temperature had an increasing trend by $0.074,0.059$ and $0.095^{\circ} \mathrm{C}$, respectively [43]. 
The bare land-use types were a significant proportion of all the study districts where the surface is predominantly covered by salt flats, volcanic lavas, rocks or sandy soils. Moreover, in 2017, cultivated land in two study districts, Afdem and Shinile, were little and scattering patches; and, it covers around 5\% in Afdem and $7 \%$ in Shinile, and it showed a significant rise in Shinile but in-consistent in Afdem. Since 2001, the tendency of increase in trends of cultivated land was stagnant. These may be due to increasing drought occurrence, particularly rainfall was reduced since 2000, and these may discourage the more involvement in agriculture. According to FGDs held in Afdem, due to the impact of drought the community forced to shift agriculture, however, due to the lack of rainfall, the cultivation remains as it was. Similarly, the KIIs result held with Afdem district's Agriculture and Natural Resource Office, indicated that the amount of land allocated 50 hectares has been cleaned for irrigation in 2017, and at the end of the year, only 20 hectares of land was used for irrigation but out of these 20 hectares of land the irrigation was effective on 12 hectares of land. Regarding, the amount of hectare of land farmed using rain-fed agriculture in Afdem district; it was 108 and 62 hectares in 2016 and 2017 respectively. Compared to Shinile district (2000 hectare were irrigated), the cultivated land in the Afdem district is the less. Generally, the respondents during FGDs and KIIs attribute the trend to increasing drought occurrence, which discourages more involvements in agriculture. From 2006-2017 years, in Shinille and Afdem districts, a total of 2000 pastoral households were shifted from pastoralism to agro-pastoralism being involved in irrigation scheme and rain feed agriculture [44].

It is also observed in the field that many cropping fields left uncultivated gradually revert to shrub land mainly dominated by annual forbs and Prosopis plant less palatable to livestock. The FGD participants described that: Prosopis was first introduced in Shinile district in 1978 as a conservation measure. It was planted by conducting community mobilization and campaigns. Prosopis has been planted to reclaim degraded land, combat desertification and reduce soil erosion [44] [45] [46]. Regarding its distribution, it mostly found in grasslands and valleys where water is available. Prosopis tap roots are able to reach a depth of 20 to $25 \mathrm{~m}$, and some Prosopis trees whose roots reached beyond this depth have been reported globally [44]. The result of FGD shows that bare land has shown an increment while grazing lands have decreased and mostly replaced by Prosopis plant. Owing to allelopathy, Prosopis plants suppress growth of other plants and threaten plant diversity in areas where Prosopis plants grow [47] [48]. But due to increased coverage of shrub lands namely Prosopis, the community has witnessed becoming a suitable habitat for wildlife and as a result, tigers, cheetah and hyena were observed in the area. At the same time, the FGD has elaborated that they observed the increase of settlement areas as pastoralists have lost their livestock and grazing lands, they become destitute and sought livelihood alternatives in kebele centers and nearby towns. It was also mentioned that the increase of sub kebeles and number of kebeles in the district since 20 years ago. 
The LULC changes that were detected in all study areas revealed, in general, the greater areas of grassland and grazing land were transformed into shrub land and cultivated land, bare land and settlement. The latter definitely implies how changes in LULC causing land degradation. This shows forced conversion of the larger part of the natural vegetation cover to agricultural land, bare land and settlement, which were constantly increased in all the three study areas. In this regard, human activities are taken basically into consideration for the expansion of huge agricultural lands through unplanned exploitation of grazing resources for the spontaneously increased population. According to KII result found from both in Shinile and Afdem district agriculture and natural office, revealed that the settlement program involved with clearing of shrub lands for settlement as well as for cultivation, in the form of irrigation and red fed agriculture were practiced in since 2010 .

The LULC changes detected in all study areas, if not monitored and controlled may result in land degradation and increase vulnerability of people. Continued land use/cover change, coupled with a drier climate, greatly affects people's livelihoods and puts the pastoralist, agro-pastoralist and small holder farmers' production system under increasing threat. The changes in LULC in study area thus indicate resource degradation and vulnerability of people. The drivers and related changes may therefore influence ecosystem functioning in rangelands through their impact on traditional mobility patterns between wet- and dry-season grazing areas. This may also lead to a decrease in the size of dry-season grazing areas, isolation of crucial habitats such as water sources, indirectly resulting in changing livestock species composition and directly disturbing some plant species that may be threatened with extinction. According to FGDs, in all study districts revealed that most pastoralists no longer keep cattle and have shifted to small ruminants (goats and sheep) that can utilize bush-encroached areas. The present tendency may lead to more land degradation if no effective restoration strategy is made. Regarding to key plant species loss, the FGD held in Ayisha and Shinille district, indicated that since the past 20 years the area had lost most of the following plant species, namely, "Maraa" (Acacia nilotica), "Qudhac" (Acacia tortilis), "Galool" (Acacia bussei), "Garas" (Dobera glabra), and "Dareemo" (Chrysopogon aucheri). But charcoal production, invasion by Prosopis plant and cactus expansion were the main reasons for losing vegetation covers. According to FGD, in the Ayesha and Afdem district, the lack of fodder for their livestock within their vicinity has become a challenge, besides, they mentioned, unavailable of key grazing areas forced them to move other areas.

The general trend observed in the study districts implies a loss of grassland cover and an increase in cultivated areas and shrub or bush land cover. The present tendency may lead to more land degradation if no assisted restoration is made. Continued LULC change, coupled with a drier climate, greatly affects people's livelihoods and puts the pastoral and agro-pastoral production system under increasing threat. 


\section{Acknowledgements}

We are grateful for financial support from the Oxfam GB and FAO, for the project "Assessing the contribution of resilience program towards reducing adverse impacts of drought in Siti zone, Somali Regional State, Ethiopia". We thank Jigjiga University for their support and facilitation services.

\section{Conflicts of Interest}

The authors declare no conflicts of interest regarding the publication of this paper.

\section{References}

[1] Kassahun, A., Snyman, H.A. and Smit, G.N. (2008) Impact of Rangeland Degradation on the Pastoral Production Systems, Livelihoods and Perceptions of the Somali Pastoralists in Eastern Ethiopia. Journal of Arid Environments, 72, 1265-1281. https://doi.org/10.1016/j.jaridenv.2008.01.002

[2] IPS (Industrial Project Service) (2002) Resource Potential Assessments and Project Identification Study of Somali Region. Agricultural Resources. Industrial Projects Service. Addis Ababa, $401 \mathrm{p}$.

[3] Kassahun, A. (2006) Characterization of Rangeland Resources and Dynamics of the Pastoral Production Systems in the Somali Region of Eastern Ethiopia. Unpublished PhD Thesis, University of the Free State, South Africa, 231 p.

[4] Behnke, R. and Metaferia, F. (2011) The Contribution of Livestock to the Ethiopian Economy-Part II. IGAD Livestock Policy Initiative Working Paper No. 02-11. IGAD, Addis Ababa, 43 p.

[5] Seid, M.A., Kuhn, N.J. and Fikre, T.Z. (2016) The Role of Pastoralism in Regulating Ecosystem Services. Revue scientifique et technique (International Office of Epizootics), 35, 435-444. https://doi.org/10.20506/rst.35.2.2534

[6] Lambin, E.F. and Geist, H.J. (2006) Land-Use and Land-Cover Change: Local Processes and Global Impacts. In: Lambin, E.F. and Geist, H., Eds., Land-Use and Land-Cover Change. IGBP Series, Springer-Verlag, Berlin, Germany, 1-8. https://doi.org/10.1007/3-540-32202-7_1

[7] Oba, G., Eric Post, P., Syvertsen, O. and Stenseth, N.C. (2000) Bush Cover and Range Condition Assessments in Relation to Landscape and Grazing in Southern Ethiopia, Landscape Ecology, 15, 535-546. https://doi.org/10.1023/A:1008106625096

[8] Kari, V. (2010) Sedenterization in Fitu woreda, Ethiopia: Impact on Health, Ecology and Society. Unpublished $\mathrm{PhD}$ Thesis, Norwegian University of Life Sciences, Norway, $201 \mathrm{p}$.

[9] Tsegayea, D., Moea, S.R., Vedeldc, P. and Aynekulud, E. (2010) Land-Use/Cover Dynamics in Northern Afar Rangelands, Ethiopia. Agriculture, Ecosystems and Environment, 139, 174-180. https://doi.org/10.1016/j.agee.2010.07.017

[10] Garedew, E. (2010) Land Use and Land Cover Dynamics and Rural Livelihood Perspectives in the Semi-Arid Areas of Central Rift Valley of Ethiopia. Ph.D. Thesis. Swedish University of Agricultural Sciences, Umea, Sweden, 156 p.

[11] Flintan, F. (2011) The Causes, Process and Impacts of Land Fragmentation in the Rangelands of Ethiopia, Kenya and Uganda: Regional Learning and Advocacy Programme for Vulnerable Dry land Communities. 
http://www.preventionweb.net/files/24288_24288summarybrieflandfragmentationf. pdf

[12] Sala, O.E., Chapin, F.S., Armesto, J.J., Berlow, E., Bloomfield, J., Dirzo, R., et al. (2000) Biodiversity-Global Biodiversity Scenarios for the Year 2100. Science, 287, 1770-1774. https://doi.org/10.1126/science.287.5459.1770

[13] Lambin, E.F., Geist, H. and Lepers, E. (2003) Dynamics of Land Use and Cover Change in Tropical Regions. Annual Review of Environment and Resources, 28, 205-241. https://doi.org/10.1146/annurev.energy.28.050302.105459

[14] Lambin, E.F. and Serneels, S. (2001) Proximate Causes of Land-Use Change in Narok District, Kenya: A Spatial Statistical Model. Agriculture, Ecosystems \& Environment, 85, 65-81. https://doi.org/10.1016/S0167-8809(01)00188-8

[15] Geist, H.J. and Lambin, E.F. (2002) Proximate Causes and Underlying Driving Forces of Tropical Deforestation. BioScience, 52, 143-150. https://doi.org/10.1641/0006-3568(2002)052[0143:PCAUDF]2.0.CO;2

[16] Elias, M., Hensel, O., Richter, U., Hülsebusch, C., Kaufmann, B. and Wasonga, O. (2015) Land Conversion Dynamics in the Borana Rangelands of Southern Ethiopia: An Integrated Assessment Using Remote Sensing Techniques and Field Survey Data. Environments, 2, 385-387. https://doi.org/10.3390/environments2010001

[17] Reid, R.S., Kruska, R.L., Muthui, N., Taye, A., Wotton, S., Wilson, C.J. and Mulatu, W. (2000) Land-Use and Land-Cover Dynamics in Response to Changes in Climatic, Biological and Socio-Political Forces: The Case of southwestern Ethiopia. Landscape Ecology, 15, 339-355. https://doi.org/10.1023/A:1008177712995

[18] Foody, G.M. (2002) Status of Land Cover Classification Accuracy Assessment Remote. Remote Sensing of Environment, 80, 185-201.

https://doi.org/10.1016/S0034-4257(01)00295-4

[19] Liavoga, B.A., Kathumo, V.M., Onwonga, R.N., Karuku, G.N. and Onyango, C.M. (2014) Assessment of Trends in Land Cover and Crop Type Change over Two Decades in Yatta Sub County, Kenya. International Journal of Fisheries and Aquatic Studies, 2, 46-52.

[20] Alemu, B., Garedew, E., Eshetu, Z. and Kassa, H. (2015) Land Use and Land Cover Changes and Associated Driving Forces in North Western Lowlands of Ethiopia. International Research Journal of Agricultural Science and Soil Science, 5, 28-44.

[21] Riché, B., Hachileka, E. and Awuor, C.B. (2009) Climate-Related Vulnerability and Adaptive-Capacity in Ethiopia's Borana and Somali. Final Assessment Report. The IISD, IUCN, CARE International and SCUK. Financial Support by the USAID and ECHAO, 89 p.

[22] SC-UK (Save the Children UK) and DPPA (Disaster Prevention and Preparedness Agency) (2008) Livelihood and Vulnerability: An Understanding of Livelihood in Somali Regional State, Ethiopia. Addis Ababa, Ethiopia, 158 p.

[23] Ethiopian NAPA (National Adaptation Programme of Action) (2007) Climate Change National Adaptation Programme of Action. Addis Ababa, Ethiopia. http://www.preventionweb.net/files/8522_eth01.pdf

[24] CSA (Central Statistical Agency) (2008) Summary and Statistical Report of the 2007 Population and Housing Census. Addis Ababa, Ethiopia.

[25] Johnson, R.B. and Onwuegbuzie, A.J. (2004) Mixed Methods Research: A Paradigm Whose Time Has Come. Educational Researcher, 33, 14-26.

https://doi.org/10.3102/0013189X033007014

http://edr.sagepub.com/content/33/7/14.full.pdf+html 
[26] Saunders, M., Lewis, P. and Thornhill, A. (2009) Research Methods for Business Students. 5th Edition, Prentice Hall, Harlow.

[27] Tillman, J.G., Clemence, A.J. and Stevens, J.L. (2011) Mixed Methods Research Design for Pragmatic Psychoanalytic Studies. Journal of the American Psychoanalytic Association, 59, 1023-1040. https://doi.org/10.1177/0003065111418650

[28] ITT (International Telephone and Telegraph) (2006) ENVI Version 4.3, ITT Industries Incorporated, Boulder, CO.

[29] Lillesand, M.T. and Kiefer, W.R. (2000) Remote Sensing and Image Analysis. 4th Edition, John Wiley \& Sons Inc., New York.

[30] Serra, P., Pons, X. and Sauri, D. (2003) Post-Classification Change Detection with Data from Different Sensors: Some Accuracy Considerations. International Journal of Remote Sensing, 24, 3311-3340. https://doi.org/10.1080/0143116021000021189

[31] CSA (Central Statistical Agency) (1994/2007) Population Censuses. Addis Ababa.

[32] Anderson, J.R., Hardy, E.E., Roach, J.T. and Witmer, R.E. (1976) A Land Use and Land Cover Classification System for Use with Remote Sensor data. Geological Survey Professional Paper 964, USGS, Washington DC.

https://doi.org/10.3133/pp964

[33] Pratt, D.J., Greenway, P.J. and Gwynne, M.D. (1966) A Classification of East Africa Rangeland, with an Appendix on Terminology. Journal of Applied Ecology, 3, 369-383. https://doi.org/10.2307/2401259

[34] Pratt, D.J. and Gwynne, M.D. (1977) Rangeland Management and Ecology in East Africa. London, Hodder and Stoughton.

[35] ESRI (Environmental Systems Research Institute) (2012) ArcGIS Desktop: Release 11. ESRI, Redlands, CA.

[36] Peng, J., Wu, J., Yin, H., Li, Z., Chang, Q. and Mu, T. (2008) Rural Land Use Change during 1986-2002 in Lijiang, China, Based on Remote Sensing and GIS Data. Sensors, 8, 8201-8223. https://doi.org/10.3390/s8128201

[37] Congalton, R. (1991) A Review of Assessing the Accuracy of Classifications of Remotely Sensed Data. Remote Sensing of Environment, 37, 35-46. https://doi.org/10.1016/0034-4257(91)90048-B

[38] Lu, D., Mausel, P., Brondizio, E. and Moran, E. (2004) Change Detection Techniques. International Journal of Remote Sensing, 25, 2365-2407. https://doi.org/10.1080/0143116031000139863

[39] Braimoh, A.K. (2006) Random and Systematic Land-Cover Transitions in Northern Ghana. Agriculture, Ecosystems \& Environment, 113, 254-263. https://doi.org/10.1016/j.agee.2005.10.019

[40] Pontius Jr., R.G. Shusas, E. and McEachern, M. (2004) Detecting Important Categorical Land Changes While Accounting for Persistence. Agriculture, Ecosystems \& Environment, 101, 251-268. https://doi.org/10.1016/j.agee.2003.09.008

[41] Maingi, J.K. and Marsh, S.E. (2002) An Accuracy Assessment of 1992 Landsat-MSS Derived Land Cover for the Upper San Pedro Watershed (U.S./Mexico). United States Environmental Protection Agency, Washington DC, 29.

[42] Landis, J.R. and Koch, G.G. (1977) The Measurement of Observer Agreement for Categorical Data. Biometrics, 33, 159-174. https://doi.org/10.2307/2529310

[43] Fikre, Z., Biniyam, B., Abdurhman, M. and Ahmed, S. (2018) Assessing the Contribution of Resilience Program towards Reducing Adverse Impacts of Drought in Siti Zone, Somali Regional State, Ethiopia. Oxfam GB and FAO, $133 \mathrm{p}$

[44] Pasiecznik, N.M. and Henry Doubleday Research Association (2001) The Prosopis 
julifora-Prosopis pallida Complex: A Monograph. HDRA, Coventry.

[45] Tessema, Y.A. (2012) Ecological and Economic Dimensions of the Paradoxical Invasive Species-Prosopis juliflora and Policy Challenges in Ethiopia. Journal of Economics and Sustainable Development, 3, 62-70. http://www.Iiste.Org

[46] Wakie, T.T., Evangelista, P.H., Jarnevich, C.S. and Laituri, M. (2014) Mapping Current and Potential Distribution of Non-Native Prosopis juliflora in the Afar Region of Ethiopia. PLoS ONE, 9, e112854. https://doi.org/10.1371/journal.pone.0112854

[47] Mosweu, S., Munyati, C., Kabanda, T., Setshogo, M. and Muzila, M. (2013) Prosopis L. Invasion in the South-Western Region of Botswana: The Perceptions of Rural Communities and Management Options. Natural Resources, 4, 496-505. https://doi.org/10.4236/nr.2013.48061

[48] Mwangi, E. and Swallow, B. (2005) Invasion of Prosopis and Local Livelihoods: Case Study from the Lake Baringo Area of Kenya. ICRAF Working Paper No. 3, World Agroforestry Centre, Nairobi, Kenya. https://doi.org/10.5716/WP13657.PDF http://www.issg.org/database/species/reference_files/progla/MwangiandSwallow_20 05.pdf 